\title{
Die teenstellingsdefinisie in Afrikaanse verklarende woordeboeke
}

\author{
Herman L. Beyer, Departement Germaanse en Romaanse Tale, \\ Universiteit van Namibië, Windhoek, Namibië
}

\begin{abstract}
The Contrastive Definition in Afrikaans Explanatory Dictionaries. This paper deals with the contrastive definition which is readily applied in Afrikaans standard explanatory dictionaries to define the female member of a gender opposition pair. The aim of the paper is to determine whether the contrastive definition is a full lexicographic definition, and whether its application is lexicographically justifiable. The terms gender opposition, gender opposition pairs, male and female members of gender opposition pairs and contrastive definition are explained at the outset. Arguments in favour of the application of the contrastive definition found in Afrikaans metalexicographic literature, are presented, followed by arguments opposing its use. The absence of an evaluation of the contrastive definition as lexicographic definition is confirmed, and such an evaluation, based on further research into the use of the contrastive definition in the Verklarende Handwoordeboek van die Afrikaanse Taal, is consequently presented. The implications of the use of the contrastive definition in terms of current lexicographic conventions and the employment of a model in terms of which lexicographic definitions can be classified, lead to the conclusion that the contrastive definition cannot be regarded as a lexicographic definition. Comparable defining strategies in non-Afrikaans dictionaries are briefly highlighted, followed by proposals for the alternative treatment of (female members of) morphologically marked gender opposition pairs.
\end{abstract}

Keywords: CONTRASTIVE DEFINITION, CROSS REFERENCE, FEMALE MEMBERS, GENDER OPPOSITION, GENDER OPPOSITION PAIRS, LEXICOGRAPHER, LEXICOGRAPHIC TREATMENT, LEXICOGRAPHIC DEFINITION, MALE MEMBERS, MORPHOLOGICALLY MARKED GENDER OPPOSITION PAIRS, REFERENCE, SEMANTIC AND SYNTACTIC INFORMATION, SEMANTIC EXPLANATION, STANDARD EXPLANATORY DICTIONARY

Opsomming: Hierdie artikel behandel die teenstellingsdefinisie wat geredelik in Afrikaanse standaard verklarende woordeboeke gebruik word om die vroulike lid van 'n geslagsopposisiepaar te definieer. Die doel van die artikel is om te bepaal of die teenstellingsdefinisie ' $n$ volwaardige leksikografiese definisie is, en of die gebruik daarvan leksikografies geregverdig is. Die terme geslagsopposisie, geslagsopposisiepare, manlike en vroulike lede van geslagsopposisiepare en teenstellingsdefinisie word ten aanvang verduidelik. Argumente ten gunste van die gebruik van die teenstellingsdefinisie aangetref in die Afrikaanse metaleksikografiese literatuur, word weergegee, gevolg deur argumente wat die gebruik van dié definisie teenstaan. Die afwesigheid van 'n evaluering van die teenstellingsdefinisie as leksikografiese definisie word bevestiz, en sodanige evaluering word vervolgens aangebied na aanleiding van verdere ondersoek na die optrede van dié definisie in die Verklarende Handwoordeboek van die Afrikaanse Taal. Die implikasies van die optrede van die teenstellingsdefinisie in terme van geldende leksikografiese konvensies en die aanwending van 'n 
model in terme waarvan leksikografiese definisies geklassifiseer kan word, lei tot die gevolgtrekking dat die teenstellingsdefinisie nie as leksikografiese definisie erken kan word nie. Vergelykbare definiëringstrategieë in nie-Afrikaanse woordeboeke word kortliks uitgewys, gevolg deur voorstelle vir die alternatiewe hantering van (vroulike lede van) morfologies gemerkte geslagsopposisiepare.

Sleutelwoorde: BETEKENISVERKLARING, GESLAGSOPPOSISIE, GESLAGSOPPOSISIEPARE, KRUISVERWYSING, LEKSIKOGRAAF, LEKSIKOGRAFIESE DEFINISIE, LEKSIKOGRAFIESE HANTERING, MANLIKE LEDE, MORFOLOGIES GEMERKTE GESLAGSOPPOSISIEPARE, SEMANTIESE EN SINTAKTIESE INLIGTING, STANDAARD VERKLARENDE WOORDEBOEK, TEENSTELLINGSDEFINISIE, VERWYSING, VROULIKE LEDE

\section{Inleiding}

Hierdie artikel behandel die teenstellingsdefinisie, wat geredelik in Afrikaanse standaard verklarende woordeboeke gebruik word om die vroulike lid van 'n geslagsopposisiepaar te definieer. Hierdie manier van definiëring is nie uniek aan die Afrikaanse leksikografie nie: in ten minste twee Duitse verklarende woordeboeke word die vroulike lede van geslagsopposisiepare op soortgelyke wyse gedefinieer.

Die doel van hierdie artikel is om te bepaal of die teenstellingsdefinisie ' $n$ volwaardige leksikografiese definisie is, en of die gebruik daarvan leksikografies geregverdig is.

Die Verklarende Handwoordeboek van die Afrikaanse Taal (Odendal, Schoonees, Swanepoel, Du Toit en Booysen 1994 - voortaan HAT) is as verteenwoordiger van die versameling Afrikaanse standaard verklarende woordeboeke as databron gebruik. Tensy anders vermeld, kom alle aangehaalde voorbeelde uit dié woordeboek. Die teenstellingsdefinisie kom ook dikwels voor in Verklarende Afrikaanse Woordeboek (Labuschagne en Eksteen 1993).

\section{Geslagsopposisie, geslagsopposisiepare en die teenstellingsdefinisie}

Ten aanvang word die volgende terme omskryf: geslagsopposisie, geslagsopposisiepare, manlike en vroulike lede van geslagsopposisiepare en die teenstellingsdefinisie.

\subsection{Geslagsopposisie en geslagsopposisiepare}

'n Semantiese verhouding van geslagsopposisie bestaan tussen twee leksikale items wat in die eerste plek ten opsigte van die semantiese kategorie [geslag] in opposisie tot mekaar staan, dit wil sê die een item bevat die semantiese komponent [+ manlik], terwyl die ander item die semantiese komponent [+ vroulik] bevat. Behalwe vir die verskil in hierdie semantiese kategorie het die twee leksikale items identiese semantiese waardes, byvoorbeeld koning x koningin (vir 
die denotasie "regeerder oor 'n koninkryk"). Die items koning en koningin word dus beskou as onderskeidelik die manlike en vroulike lede van die geslagsopposisiepaar koning $x$ koningin. Volgens Beyer (1997: 114) bestaan 'n geslagsopposisiepaar "slegs uit 'n [+ manlik]-gemerkte leksikale item en die teenoorstaande [+ vroulik]-gemerkte leksikale item. Geslagsopposisiepare bevat dus nié geslagtelik neutrale (dit is [ \pm manlik]-gemerkte) leksikale items nie." In 'n geslagsopposisiepaar soos onderwyser $x$ onderwyseres is die [ \pm manlik]-gemerkte waarde van die leksikale item onderwyser dus nie ter sprake nie; dié waarde geld as aparte polisemiese waarde van die leksikale item onderwyser as superordinaat van beide lede van die geslagsopposisiepaar, hoewel hierdie feit nie in Afrikaanse verklarende woordeboeke verantwoord word nie (vgl. Beyer 1997). Dit is dus duidelik dat dit ook by die semantiese verhouding van geslagsopposisie nie "' $n$ leksikale item is wat in een of ander verhouding staan tot ' $n$ ander leksikale item nie, maar eerder die een of ander polisemiese waarde van die betrokke leksikale item (poliseem) wat in 'n bepaalde verhouding staan tot die een of ander polisemiese waarde van 'n ander leksikale item" (De Stadler 1989: 85).

Oor die aard van die semantiese verhouding van geslagsopposisie bestaan uiteenlopende standpunte. Fouché (1990: 91) benader geslagsopposisie as 'n verhouding van komplementariteit, terwyl Combrink (1990: 108) betoog "[+ manlik] en [+ vroulik] is nie binêr teenoorgestelde eienskappe nie - hulle is punte op 'n skaal". Combrink se siening maak egter slegs voorsiening vir die polisemiese waarde "met tipiese manlike/vroulike eienskappe" van 'n leksikale item (geslag as ' $n$ karakteristieke kenmerk van die referent), maar nie vir die polisemiese waarde "behorende tot die manlike/vroulike geslag" (geslag as 'n inherente kenmerk van die referent) nie. Die geslag waaraan 'n referent (inherent) behoort, kan nie op 'n skaal geleë wees nie - dit is ' $n$ vaste gegewe (kenmerk), maar die karakteristieke wat 'n referent openbaar, kan die referent wel op 'n skaal met die punte (kenmerke) "manlikheid" (Eng. "masculinity") en "vroulikheid" (Eng. "femininity") plaas (vgl. De Stadler 1989: 85). Die semantiese verhouding van geslagsopposisie slaan slegs op geslag as inherente kenmerk van die betrokke referente.

Die siening dat geslagsopposisie 'n verhouding van komplementariteit verteenwoordig, is ook nie sonder meer geldig nie. Volgens Beyer (1997: 108) behoort daar eerder sprake te wees van 'n verhouding van gedeeltelik komplementêre opposisies: "'n Komplementêre geslagsopposisiepaar ontstaan [...] eintlik slegs wanneer 'n ooreenkomstige komplementêre opposisieverhouding deur 'n bepaalde konteks geaktiveer word." So byvoorbeeld kan onderwyser óf die komplement onderwyseres óf die komplement leerling neem, na gelang van die konteks waarin onderwyser optree. Beide die leksikale items is gedeeltelike komplemente van die item onderwyser.

Vir die doel van hierdie artikel word geslagsopposisie dus as 'n semantiese verhouding van gedeeltelike komplementariteit met die semantiese kategorie [geslag] as diagnostiese kenmerk beskou. 


\subsection{Die teenstellingsdefinisie}

Met die term teenstellingsdefinisie word verwys na dié leksikografiese meganisme wat blykbaar eksklusief aangewend word in die beskrywing van morfologies gemerkte vroulike lede van geslagsopposisiepare, dit wil sê vroulike lede wat van [+ manlike] of [- animate] stamme afgelei word deur die aanvoeging van sogenaamde vervroulikingsuffikse. Vergelyk die geslagsopposisiepaar baron $x$ barones in (1)(a) as tipiese voorbeeld waar die vroulike lid van in [+ manlike] stam afgelei is, en (1)(b) as tipiese voorbeeld waar die vroulike lid van 'n [- animate] stam afgelei is:

(1) (a) baron (stam, manlike lid) + -es (vervroulikingsuffiks) $\rightarrow$ barones (vroulike lid)

(b) bak ([- animate] stam) + -ster (vervroulikingsuffiks) $\rightarrow$ bakster (vroulike lid)

In HAT neem die teenstellingsdefinisie die vorm van 'n formule aan wat geïdentifiseer is deur die vorm van die meerderheid van die opgetekende teenstellingsdefinisies, naamlik

(2) [vroulike lid van geslagsopposisiepaar] Vr. vorm van [manlike lid van geslagsopposisiepaar]

byvoorbeeld

(3) (a) barones Vr. vorm van baron.

(b) bakster Vr. vorm van bakker.

In die Afrikaanse metaleksikografiese literatuur word hierdie soort definisie aanvaar (vgl. Fouché 1990 en Gouws 1989), maar nie verduidelik of gemotiveer nie. Fouché (1990: 149) plaas die definisie saam met die sogenaamde verkleiningsdefinisie in ' $n$ vae kategorie wat genoem word "definisies wat semantiese pluswaardes ekspliseer" en wat blykbaar op dieselfde vlak as die ander hoofsoorte leksikografiese definisies funksioneer. Hierdie stand van sake vra om nadere ondersoek, waarvan in die volgende paragrawe verslag gedoen word.

\section{Argumente ten gunste van die gebruik van die teenstellingsdefinisie}

Die bestaande argumente ten gunste van'die aanwending van die teenstellingsdefinisie word vervolgens slegs weergegee; relevante kritiek op dié argumente vloei uit die res van die bespreking voort. 


\subsection{Eksplisering van semantiese pluswaarde}

Volgens Zgusta (1971: 253) is die funksie van die leksikografiese definisie om die gedefinieerde leksikale item te differensieer van die ander leksikale items: "The lexicographic definition enumerates only the most important semantic features of the defined lexical unit, which suffice to differentiate it from other units." Gouws (1989: 159) ondersteun ook die aanwending van die teenstellingsdefinisie, byvoorbeeld by die lemma onderwyseres: "Semanties is dit bevredigend aangesien die betekenisverklaring by die lemma onderwyser gegee word en die definiens by onderwyseres die onderskeidende semantiese waarde tussen dié twee woorde duidelik stel." Volgens Fouché (1990: 151) besit die morfologies gemerkte vroulike vorm 'n semantiese pluswaarde, naamlik dié van vroulik, wat die aanwending van die teenstellingsdefinisie regverdig, aangesien dié semantiese pluswaarde sodoende geëkspliseer word. Dit is dan die eksplisering van hierdie semantiese pluswaarde wat voldoende is om die betekenis van die vroulike vorm van dié van die manlike vorm te onderskei.

\section{2 \\ Funksie van betekenisverklaring en verwysing}

Die teenstellingsdefinisie vervul 'n dualistiese funksie daarin dat dit ' $n$ betekenisverklaringsaspek sowel as 'n verwysingsaspek bevat. Volgens Beyer (1995: 53) het die teenstellingsdefinisie die volgende twee funksies:

(4) (a) Die teenstellingsdefinisie ekspliseer ' $n$ bepaalde opposisieverhouding tussen twee leksikale items, naamlik dié leksikale item wat as definiendum van die teenstellingsdefiniens optree en dié leksikale item in terme waarvan die lemma verklaar word.

(b) Die teenstellingsdefinisie dien terselfdertyd as ('n vorm van onregstreekse) betekenisverklaring van die lemma waar dit aangewend word.

Fouché (1990: 150) ondersteun hierdie standpunt: "Wanneer-'n teenstellingsdefinisie gebruik word, word die definiendum se semantiese betrekkinge met 'n ander leksikale item duidelik" sonder dat dit nodig sou wees om bykomende semantiese inligting deur verdere inskrywings te voorsien.

Vanuit 'n praktiese oogpunt werk die teenstellingsdefinisie dus ruimtebesparing in die hand.

\subsection{Taalkundige inligting}

Die aanwending van die teenstellingsdefinisie bevorder die akkuraatheid van taalkundige inligting wat in die woordeboek weergegee word. 
Volgens Beyer (1995: 22-23) is die semantiese verskil tussen die manlike en vroulike lede van 'n morfologies gemerkte geslagsopposisiepaar kongruent aan die morfologiese verskil tussen hulle. Hierdie kongruensie word akkuraat deur die teenstellingsdefinisie weergegee. Ilson (1987:63) wys ook op "the usefulness of formulaic definitions for giving morphological information: they incorporate words linked morphologically to their definienda. In a very real sense the information they give is etymological in nature [...]."

Die teenstellingsdefinisie is ook ' $n$ akkurate beskrywing van die aard van die semantiese verhouding ter sprake (nl. gedeeltelike komplementariteit, vgl. 2.1) deur die formulering "Vr. vorm van ...", en nie bloot "teenoor" (wat volledige komplementariteit sou suggereer) nie, hetsy in die definiens, hetsy deur middel van ' $n$ addisionele inskrywing.

\section{Argumente teen die gebruik van die teenstellingsdefinisie}

Argumente in die Afrikaanse metaleksikografiese literatuur wat die gebruik van die teenstellingsdefinisie teenstaan, kom hoofsaaklik vanuit 'n sosiolinguistiese perspektief.

\subsection{Opname van vroulike vorme}

Volgens Beylefeld en Van Jaarsveld (1994: 46-47) is die lemmastatus van vroulike lede van morfologies gemerkte geslagsopposisiepare "twyfelagtig aangesien die betekenisleiding slegs per kruisverwysing as 'vroulik van...' aangegee word - selfs in gevalle waar die vroulike vorm volgens alfabetiese rangorde voor die manlike vorm gelys is [...]. In die lig hiervan, is die eksplisiete [+ vroulik]-gemerktheid van beroepsbenaminge oorbodig en 'n vermorsing van ruimte." Dit is duidelik dat Beylefeld en Van Jaarsveld nie die teenstellingsdefinisie as leksikografiese definisie erken nie - hulle beskou dit as 'n blote kruisverwysingsmiddel. Afgesien hiervan is hulle kritiek wat die lemmastatus van die vroulike lede betref, leksikografies ongegrond. Die doel van enige standaardwoordeboek is om die leksikale items van die standaardtaal te verklaar. Indien die vroulike lede van morfologies gemerkte geslagsopposisiepare die standaardtaal verteenwoordig, moet hulle as lemmas in die woordeboek opgeneem word. Gouws (1989: 159) stel dit ook kategories dat beide lede van 'n geslagsopposisiepaar as volle lemmas hanteer behoort te word. Dié stelling kan wel gekwalifiseer word deur die voorwaarde dat beide lede verteenwoordigend van die standaardtaal moet wees. Dit sal dus byvoorbeeld nie nodig wees om die volle geslagsopposisiepaar beer $\mathrm{x}$ berin of sot $\mathrm{x}$ sottin in die makrostruktuur op te neem nie, aangesien die items berin en sottin verouderde taalgebruik verteenwoordig, wat in elk geval impliseer dat die items beer en sot volledig geslagtelik geneutraliseer is. Van der Merwe (1994: 232) stel dit ook "dat 'n handwoordeboek nie historiese vorme, dialektiese vorme, sleng en tegniese vorme [moet] opneem nie. 'n Gebruiker van 'n handwoordeboek [as tipiese ge- 
bruiker - HLB] stel ook nie in etimologiese inligting en verouderde taalgebruik belang nie." Hierdie kriteria behoort die enigste maatstaf te wees waarvolgens ' $n$ item se lemmastatus in 'n standaardwoordeboek bepaal word.

Beylefeld en Van Jaarsveld (1994: 44) is egter van mening dat "indien dit so is dat die meerderheid Afrikaanse moedertaalsprekers nog vassteek by konvensioneel seksistiese taalgebruik, behoort woordeboekmakers dit hul plig te ag om alternatiewe, nieseksistiese taalvorme en -gebruik te vestig." Hierdie siening is onaanvaarbaar, aangesien dit die taak van die verklarende leksikograaf is om die inhoud van die leksikon te beskryf, en nie om preskriptief op te tree nie. Volgens Spender (1980: 29-30) is daar boonop "fundamental problems with the creation of new words because while they are also subjected to the existing semantic rule that male is positive and minus male is negative, there is reason to believe that when consigned to negative semantic space they too will become pejorated and sexist. It is the semantic rule which needs to change, not the words themselves, yet this suggestion has rarely arisen in language/sex research." Vanuit 'n leksikografiese oogpunt moet Romaine (1994: 127) se standpunt geld "that society's perceptions of men and women must change in order for linguistic reform to be successful." Uiteindelik sal die taalgebruiker bepaal of sekere items langer in die verklarende woordeboek opgeneem sal word.

Die aanwending van die teenstellingsdefinisie by morfologies gemerkte geslagsopposisiepare is ook nie beperk tot beroepsbenaminge nie: vergelyk die gebruik van dié definisie by die vroulike lede van die geslagsopposisiepare eienaar $\mathrm{x}$ eienares, speler $\mathrm{x}$ speelster, voorsitter $\mathrm{x}$ voorsitster, beer $\mathrm{x}$ berin en leeu $\mathrm{x}$ leeuin (hoewel laasgenoemde twee se vroulike lede verouderde taalgebruik verteenwoordig).

\subsection{Vroulike vorme se betekenisbeskrywing}

Beylefeld en Van Jaarsveld (1994: 47) lewer verdere kritiek op die gebruik van die teenstellingsdefinisie vanuit 'n sosiolinguistiese oogpunt: "Op die semantiese vlak vorm manlikheid dus die domein waarbinne die vroulike beroepsbekleder [of vroulike lid van die geslagsopposisiepaar - HLB] betekenis moet verkry." Hierdie punt van kritiek blyk geldig te wees, aangesien dit die primêre rede is vir die huidige niegebruik van die teenstellingsdefinisie in die Woordeboek van die Afrikaanse Taal (WAT) (W.F. Botha en A.E. Cloete (Buro van die WAT) - persoonlike mededeling). Fouché (1990: 151) se siening dat die vroulike lid van 'n morfologies gemerkte geslagsopposisiepaar 'n semantiese pluswaarde besit (vgl. 3.1), word ook deur hierdie kritiek onder verdenking geplaas.

\section{Die teenstellingsdefinisie as leksikografiese definisie}

Geeneen van die bestaande argumente raak die geldigheid al dan nie van die teenstellingsdefinisie as leksikografiese definisie aan nie. Die feit dat daar 
onder teoretici blykbaar nie eenstemmigheid is oor die blote bestán van dié definisie nie (vgl. Beylefeld en Van Jaarsveld 1994 se siening in 4.1) is rede genoeg om verdere ondersoek te regverdig. Vervolgens word die argumente voortspruitend uit sodanige ondersoek aangebied.

\subsection{Beperkte semantiese gebruik}

Die aanwending van die teenstellingsdefinisie blyk beperk te wees tot 'n bepaalde soort opposisieverhouding, naamlik geslagsopposisie. Dit is hierdie beperkte aanwending wat dit verdag maak. Ander soorte opposisieverhoudings word gewoonlik deur verwysings naas die betekenisverklaring (wat deur middel van enige ander leksikografiese definisie gedoen word) gemaak deur byvoorbeeld die merkers teenoor en vergelyk te gebruik. Daar bestaan geen ander leksikografiese definisie wat eksklusief aangewend word in die eksplisering van ' $n$ bepaalde leksikale opposisieverhouding nie.

Die teenstellingsdefinisie is ook nie noodsaaklik in die betekenisverklaring van die vroulike lid van 'n geslagsopposisiepaar nie; dié definisie kan maklik deur enige ander leksikografiese definisie vervang word sonder om suksesvolle betekenisverklaring in die gedrang te bring. Addisioneel tot die aanwending van enige ander leksikografiese definisie kan 'n blote verwysing dan 'n leksikale opposisieverhouding ekspliseer. Beylefeld en Van Jaarsveld (1994: 46) beskou die teenstellingsdefinisie inderdaad slegs as 'n verwysing (vgl. 4.1).

\subsection{Beperkte leksikale bestek}

$\mathrm{Na}$ aanleiding van Combrink (1990: 105-106) word die vroulike lede van geslagsopposisiepare op drie maniere geleksikaliseer. Eerstens bestaan daar afsonderlike leksikale items (stamme) vir vroulike referente, byvoorbeeld dogter, vrou en hen. Tweedens bestaan daar komposita met [+ vroulike] stamme soos dames-, -vrou en wyfie-/-wyfie. Derdens bestaan daar afleidings met [+ manlike] stamme en [+ vroulike] suffikse, byvoorbeeld barones, koningin en onderwyseres, en afleidings met [- animate] stamme en [+ vroulike] suffikse, byvoorbeeld bakster, helpster en speelster.

Daar is reeds melding gemaak dat die teenstellingsdefinisie slegs by morfologies gemerkte geslagsopposisiepare aangewend word. Eersgenoemde kategorie vroulike lede van geslagsopposisiepare (vroulike lede as afsonderlike leksikale items), wat nie produkte van morfologiese prosesse is nie, word dus nie deur hierdie definisie gedek nie. Dit veroorsaak 'n diskrepansie, aangesien daar geen semantiese verskil tussen leksikale en morfologies gemerkte geslagsopposisiepare bestaan nie.

Dié diskrepansie word vergroot deur die feit dat die teenstellingsdefinisie slegs optree by vroulike lede van morfologies gemerkte geslagsopposisiepare wat produkte van suffigering is. Kompositumprodukte word ook nie deur die teenstellingsdefinisie gedek nie. 
Slegs een van die drie maniere waarop die semantiese verhouding van geslagsopposisie geleksikaliseer word, word deur die teenstellingsdefinisie verantwoord. Dit blyk dus duidelik dat die aanwending van die teenstellingsdefinisie morfologies gemotiveer is, en nie semanties nie. Hierdie stand van sake strook nie met die primêre motivering vir die gebruik van die leksikografiese definisie nie, naamlik die weergee van semantiese inligting.

\section{3}

\section{Beperkte optrede}

Die aanwending van die teenstellingsdefinisie by suffigaal gemerkte vroulike lede van geslagsopposisiepare veronderstel oënskynlik nie die konsekwente optrede van dié definisie by sulke lemmas nie. ${ }^{2}$ Vergelyk die HAT-uittreksels in (5) en (6):

(5) (a) tikker Manlike persoon wat (as beroep) met 'n tikmasjien tik.

(b) tikster Vroulike persoon wat as beroep met 'n tikmasjien tik.

(6) (a) verpleër Man wat spesiaal opgelei is om siekes te verpleeg.

(b) verpleegster Vroulike persoon wat spesiaal opgelei is om siekes te verpleeg.

Teen die agtergrond van die inkonsekwente toepassing van leksikografiese beginsels in Afrikaanse woordeboeke bestaan daar twee perspektiewe waaruit die hantering van die geslagsopposisiepare in (5) en (6) verklaar kan word.

Die eerste verklaring steun op die feit dat die vroulike lede ter sprake nie afgelei is van die manlike lede nie, maar van dieselfde stamme as waarvan die manlike lede sélf afgelei is. Die morfologiese verskil tussen die manlike en vroulike lede is dus nie kongruent aan die semantiese verskil tussen hulle nie; derhalwe sou die optrede van 'n teenstellingsdefinisie by die vroulike lede nie 'n akkurate weergawe van taalkundige inligting verteenwoordig nie (vgl. 3.3). Indien hierdie verklaring die geldende een is, word dit nie konsekwent toegepas nie: die lemmas bakster, helpster, waarsegster en skryfster word byvoorbeeld wel deur teenstellingsdefinisies verklaar.

Die tweede verklaring steun op die waarskynlikheid (na aanleiding van die uitsonderings by die eerste verklaring) dat die leksikograaf nie die semanties-morfologiese kongruensie (vgl. 3.3) in ag geneem het by die hantering van die lemmas in (5)(b) en (6)(b) nie, maar dat die vroulike lede telkens volledig verklaar is omdat hulle die mees gebruiklike items in algemene taalgebruik is, terwyl die manlike lede selde voorkom. Beide lede van elke geslagsopposisiepaar word dus van volledige betekenisverklarings voorsien. Die vraag wat dan tereg gevra mag word, is waarom die manlike lid nie deur 'n teenstellingsdefinisie soos

\section{tikker Manlike vorm van tikster}

verklaar word nie. 
Dit is duidelik dat beide verklarings nie houdbaar is nie, en verdere meriete word aan Beylefeld en Van Jaarsveld (1994: 46) se sosiolinguistiese kritiek in 4.2 verleen.

Ten spyte van bogenoemde verklarings vir die nieoptrede van die teenstellingsdefinisie by sommige suffigaal gemerkte geslagsopposisiepare het die semantiese verhouding van geslagsopposisie tussen die betrokke lede onveranderd gebly. Weer eens word dit duidelik dat die optrede van die teenstellingsdefinisie eerder morfologies as semanties gemotiveer is (hoewel selfs die morfologiese motivering blykbaar nie konsekwent toegepas word nie).

\subsection{Beperkende optrede}

Die optrede van die teenstellingsdefinisie kan die implisiete of eksplisiete stel van ander leksikale betrekkinge waarin die definiendum tot ander leksikale items in die makrostruktuur mag staan, verhinder. Vergelyk die hantering van die lemma regisseuse:

$$
\text { regisseuse Vroulike vorm van regisseur; spelleidster. }
$$

Indien spelleidster hipoteties gesproke die mees gebruiklike lid van die sinoniemparadigma [regisseuse, spelleidster] is (soos wat die bewerking in (8) inderdaad wil suggereer), behoort die lemma regisseuse slegs deur ' $n$ sinoniemdefinisie verklaar te word. Die teenstellingsdefinisie is dus onnodig.

Indien die manlike lid regisseur verder hipoteties gesproke die mins gebruiklike lid van die sinoniemparadigma [regisseur, spelleier] sou wees, sou die lemma regisseur deur ' $n$ sinoniemdefinisie ("spelleier") verklaar word. Die woordeboekgebruiker wat die betekenis van regisseuse sou soek, word dus deur die teenstellingsdefinisie (as primêre definisie) verwys na die lemma regisseur, en dan weer verder verwys na die lemma spelleier. Dit is duidelik dat hierdie verwysingsnetwerk nie gebruikersvriendelik is nie. Volgens Fouché (1990: 105) is dit wenslik dat die woordeboekgebruiker nie meer as een keer na 'n ander woordeboekartikel verwys moet word nie.

Die feit dat die teenstellingsdefinisie slegs een bepaalde leksikale betrekking weergee, veroorsaak dat sy optrede beperkend inwerk op die weergee van ander semantiese inligting. Die omgekeerde is ook waar: die weergee van ander semantiese inligting in die mikrostruktuur werk beperkend op die konsekwente toepasbaarheid van die teenstellingsdefinisie in.

\subsection{Semantiese en sintaktiese inligting}

Beyer (1995: 50-63) het die teenstellingsdefinisie as leksikografiese definisie ondersoek deur dit te vergelyk met die deskriptiewe definisie en die sinoniemdefinisie, en kom tot die gevolgtrekking dat "uit die aard van die semantiese funksies wat die teenstellingsdefinisie in die verklarende woordeboek vervul, 
kan die teenstellingsdefinisie nie onvoorwaardelik as leksikografiese definisie beskou word nie". Hierdie gevolgtrekking word gebaseer op die feit dat die teenstellingsdefinisie die aanduiding van 'n leksikale betrekking voorop stel, en nie in die eerste plek betekenisbeskrywend optree nie (vgl. (4) in 3.2).

Die toepassing van Ilson (1987) se ontleding van leksikografiese definisies lewer die deurslaggewende kommentaar op die teenstellingsdefinisie as leksikografiese definisie. Volgens Ilson (1987: 72) is daar "a list of types of information provided by [lexicographic] definitions. Definitions can then be classified by the ways this information is distributed in them."

'n "Vervangbare" leksikografiese definisie gee volgens Ilson (1987: 61) vier soorte inligting oor die definiendum:

SIN 1: sintaktiese hoofkategorie, byvoorbeeld s.nw., ww.

2: sintaktiese subkategorie, byvoorbeeld indien s.nw.: soortnaam, massanaam, ens.

SEM 1: semantiese kategorie: Januarie is ' $n$ maand; om pragtig te wees, is om mooi te wees.

2: semantiese subkategorie: Januarie is die eerste maand; om pragtig te wees, is om baie mooi te wees.

Die leksikografiese definisie wat aangewend word by die lemma onderwyser kan nou in terme van Ilson (1987) ontleed word:

onderwyser Persoon [SIN 1, 2; SEM 1] wat na afgelegde eksamen bevoeg verklaar is om les te gee [SEM 2].

Dié definisie is in terme van die analise suksesvol, aangesien al vier genoemde tipes inligting daarin verantwoord word. Vergelyk nou die analise van die teenstellingsdefinisie by die lemma onderwyseres:

\section{onderwyseres Vr. vorm van onderwyser [SIN 1,2].}

Dit blyk dat die teenstellingsdefinisie nie ewe suksesvol is in die weergee van die vereiste inligting nie. SEM 2 sou nie na die woorde "vr. vorm" geplaas kon word nie, aangesien die formulering slaan op vorm, en nie op betekenis nie. SEM 1 sou ook nie na "onderwyser" in die definiens geplaas kon word nie, aangesien die formulering van die teenstellingsdefinisie 'n geslagsopposisieverhouding daarstel (vgl. 3.3), wat veronderstel dat die item onderwyser in die definiens slaan op die [+ manlike] referent (die komplement of kohiponiem), en nie op die [ \pm manlike] referent (die superordinaat) nie (vgl. die aard van geslagsopposisie in 2.1).

'n Genus-differentia definiens sou die vereiste inligting suksesvoller weergee, soos uit die volgende analise duidelik is:

vroulike [SEM 2] onderwyser [SIN 1, 2; SEM 1]. 
'n Voorwaarde vir dié definiens om suksesvol te wees, is dat die verwysing na onderwyser nié verwysing na die manlike lid van die geslagsopposisiepaar moet wees nie, maar na die [ \pm manlik]-gemerkte superordinaat onderwyser (vgl. 2.1). Die relevante poliseem van die lemma onderwyser moet dus in die definiens aangedui word, byvoorbeeld

vroulike onderwyser (onderwyser bet. 1).

Die geldigheid van hierdie voorwaarde word ondersteun deur die analise van die teenstellingsdefinisie by ' $n$ lemma soos barones, waar daar geen geslagtelik neutrale superordinaat geld nie:

\section{barones Vr. vorm van baron [SIN 1, 2].}

In (13) is daar geen sprake van enige semantiese inligting wat oorgedra word nie. Die leksikografiese hantering in (13) is op semantiese vlak vergelykbaar met die onsuksesvolle definisie

\section{driehoek Driehoekige vorm van 'n vierkant [SIN 1, 2]}

vir 'n konteks waarin vierkant en driehoek komplemente van mekaar is. ${ }^{3}$

'n Driehoek kan nie as 'n soort vierkant gedefinieer word nie, aangesien die twee konsepte mekaar wedersyds uitsluit; insgelyks kan 'n barones nie as in soort baron gedefinieer word nie, ensovoorts.

Hierdie stand van sake onderstreep die onsuksesvolle hantering van die lemma beskermvrou in (15):

\section{beskermvrou Beskermheer wat ' $n$ vrou is.}

Die leksikografiese definisie is volgens Ilson (1987: 71) "the de-lexicalisation of a lexical unit into semantic and syntactic components which are then presented in a single phrase whose content characterises the definiendum semantically and whose form characterises the definiendum syntactically". Dit word duidelik dat die teenstellingsdefinisie op sy beste slegs aan die helfte van Ilson se beskrywing van 'n leksikografiese definisie voldoen. Verder is die metataal wat in die teenstellingsdefinisie geld, nie die gewenste register vir suksesvolle definiëring nie: "If definitions succeed at all, it is because they are couched in natural language - typically, though not necessarily, in the same language as the definiendum. [...] It is probably a better metalanguage than any artificially constructed language can be [...]" (llson 1987: 71-72; my kursivering - HLB).

\subsection{Gevolgtrekking}

Dit is duidelik dat die teenstellingsdefinisie nie as 'n leksikografiese definisie beskou kan word nie. Sy aanwending as sodanig kan ook nie leksikografies 
geregverdig word nie. Leksikograwe wat akkurate taalkundige inligting in hulle woordeboeke wil oordra, sal moet afsien van die gebruik van die teenstellingsdefinisie, en moet terugkeer na die bestaande en beproefde, volwaardige leksikografiese definisies.

\section{Ander woordeboeke}

Daar bestaan ook nie-Afrikaanse woordeboeke waarvan die hantering van die vroulike lede van geslagsopposisiepare vergelykbaar is met die aanwending van die teenstellingsdefinisie in Afrikaanse woordeboeke. Hier word volstaan met enkele sodanige voorbeelde en kriptiese opmerkings.

Vergelyk die hantering van die geslagsopposisiepare König $\times$ Königin en Lehrer $\mathrm{x}$ Lehrerin in Deutsches Wörterbuch (Wahrig 1987: 771, 825):

(a) König höchster Herrscher eines Staates [...]

(b) Königin weibl. König [...] (weibl. "weiblich" - HLB)

(a) Lehrer jmd., der beruflich lehrt, unterrichtet [...]

(b) Lehrerin weibl. Lehrer

Vergelyk bogenoemde hantering met die hantering van dieselfde lemmas in 'n ander Duitse woordeboek, Deutsches Wörterbuch (Mackensen 1977; 609, 659):

(18) (a) König Beherrscher eines Königreichs [...]

(b) Königin [...] Herrscherin eines Königreichs [...]

(19) (a) Lehrer Berufserzieher [...]

(b) Lehrerin w ( $w$ "weiblich" - HLB)

Dit blyk dat verskillende woordeboeke binne een taal se hantering van geslagsopposisiepare kan verskil, en dat verskillende metodes ook in een woordeboek gebruik kan word. Dit geld ook Afrikaanse woordeboeke. Die hantering van die lemmas in (16)(b), (17)(b) en (19)(b) is aan dieselfde kritiek onderworpe as wat op die teenstellingsdefinisie in Afrikaanse woordeboeke van toepassing is.

Die Oxford Advanced Learner's Dictionary (Cowie 1989: 1431) hanteer die morfologies gemerkte geslagsopposisiepaar waiter $\mathrm{x}$ waitress as volg:

waiter (fem. wait.ress [...]) $n$ person employed to take customers' orders [...]

Die item waitress beskik nie oor volle lemmastatus nie, en word opgeneem in die gleuf vir grammatiese (morfologiese) inligting. Hierteenoor hanteer The Concise Oxford Dictionary of Current English (Allen 1990: 1379) dié geslagsopposisiepaar soos volg:

(21) (a) waiter 1 a man who serves at table in a hotel or restaurant etc. 2 [...]

(b) waitress a woman who serves at table in a hotel or restaurant etc. 
Die Collins Cobuild English Dictionary (Sinclair 1995: 1876) en Chambers-Macmillan South African Student's Dictionary (Grearson en Higgleton 1996: 1113) hanteer die geslagsopposisiepaar soortgelyk aan die hantering in (21). Wat wel telkens ontbreek, is kruisverwysings tussen die manlike en vroulike lede.

\section{Voorgestelde hantering}

Beide lede van 'n geslagsopposisiepaar wat die standaardtaal verteenwoordig, behoort volle lemmastatus in 'n standaard verklarende woordeboek te hê, en elke lemma moet volledig verklaar word. 'n Verwysing na die teenoorstaande lid van die geslagsopposisiepaar behoort as bykomende inskrywing by die mikrostruktuur ingesluit te wees. Vergelyk die voorgestelde hantering van die geslagsopposisiepare onderwyser $\mathrm{x}$ onderwyseres en koning $\mathrm{x}$ koningin:

(22) (a) onderwyser 1. Persoon wat na afgelegde eksamen bevoeg verklaar is om les te gee, [ens.].

2. Manlike onderwyser (onderwyser bet. 1); vr. onderuyseres.

(b) onderwyseres Vroulike onderwyser (onderwyser bet.1); ml. onderuyser (bet.2).

(23) (a) koning 1. Manlike regeerder oor 'n koninkryk; vr. koningin (bet.1) . 2. [...]

(b) koningin 1. Vroulike regeerder oor 'n koninkryk; ml. koning (bet.1). 2. [...]

Dit is belangrik dat die manlike en vroulike lede van 'n bepaalde geslagsopposisiepaar verbaal so identies moontlik verklaar moet word. Sodoende kan die leksikograaf en sy/haar woordeboek nie van geslagsvoorkeur verdink word nie, en dra die bewerking by tot die sosiale gelykstel van die twee geslagte.

Die implementering van hierdie hanteringswyse behoort nie ingrypend ruimte in die woordeboek in beslag te neem nie, aangesien die minderheid vroulike lede van geslagsopposisiepare volgens Combrink (1990: 106) deur suffigering gevorm word; vroulike lede wat nie deur suffigering gevorm is nie, word buitendien tans oorwegend volledig in verklarende woordeboeke beskryf. Die nodige kruisverwysings kan slegs ingevoeg word.

\section{Slot}

Hoewel in hierdie artikel hoofsaaklik op morfologies gemerkte geslagsopposisiepare gekonsentreer is, word die hoop uitgespreek dat leksikograwe die algemene hantering van geslagsopposisie in (Afrikaanse) verklarende woordeboeke sal herevalueer.

\section{Aantekeninge}

1. Die semantiese komponent [animaat] word hier gebruik soos dit deur David Crystal ( $A$ Dictionary of Linguistics and Phonetics. Oxford: Blackwell) gedefinieer word: "A term used in the 
grammatical classification of words (especially nouns) to refer to a subclass whose reference is to persons and animals, as opposed to inanimate entities and concepts" (1991": 19).

2.

Vir die doel van hierdie artikel word daar ' $n$ onderskeid getref tussen die terme aanwending en optrede. Met aanwending word bedoel dat dit geredelik moontlik is (in terme van geldende leksikografiese konvensies) vir 'n definisie om as 'n bepaalde inskrywing op te tree, terwyl met optrede verwys word na die fisiese verskyning of optrede van 'n definisie waar dit aangewend kan word. Die moontlikheid van aanwending veronderstel dus nie noodwendig optrede nie: die teenstellingsdefinisie word so byvoorbeeld aangewend in die beskrywing van vroulike lede van morfologies gemerkte geslagsopposisiepare, maar tree nie noodwendig op by elke sodanige vroulike lid nie.

3. 'n Algemene komponensiële analise van die betrokke items vir die gegewe konteks verduidelik die vergelykbaarheid tussen hulle:

$\begin{array}{llll}\text { baron } & \text { barones } & \text { vierkant } & \text { driehoek } \\ \text { [+menslik] } & \text { [+ menslik] } & \text { [+ figuur] } & \text { [+ figuur] } \\ \text { [+ adellik] } & \text { [+ adellik] } & \text { [+ geometries] } & \text { [+ geometries] } \\ \text { [+ manlik] } & \text { [+ vroulik] } & \text { [+ vierkantig] } & \text { [+driehoekig] }\end{array}$

In beide pare items verskil die lede slegs ten opsigte van een semantiese komponent. Soos wat die teenstellingsdefinisie slegs hierdie verskil tussen baron en barones weergee, dui die definiens in (14) slegs die enkele verskil tussen vierkant en driehoek aan. Daar sou wel geargumenteer kon word dat die semantiese komponente [+ vierkantig] en [+ driehoekig] verder onderverdeel kan word in onderskeidelik die komponente [+ 4 sye], [+ $90^{\circ}$-hoeke] en [+ 3 sye], [-90'-hoeke], en dat hierdie komponente die eintlike definiense van die betrokke items sou konstitueer. Die semantiese komponente [+ manlik] en [+ vroulik] sou egter elk ook in verdere komponente onderverdeel kon word om meer tegniese definiense vir die items baron en barones daar te stel!

In aansluiting by Beylefeld en Van Jaarsveld (1994: 46) se sosiolinguistiese kritiek in 4.2 sou tereg gevra kon word na die rede waarom die leksikograaf besluit het om die item driehoek in terme van die item vierkant te definieer, en nie byvoorbeeld andersom nie.

Vergelyk hierteenoor die suksesvoller definisies vir dieselfde konteks:

vierkant Vierkantige geometriese figuur; vgl. driehoek

driehoek Driehoekige geometriese figuur; vgl. vierkant

Die items vierkantig en driehoekig (soos manlik en vroulik) word elders in die makrostruktuur opgeneem en verklaar in terme van die genoemde komponente waarin hulle onderverdeel kan word.

\section{Verwysings}

\section{Woordeboeke}

Allen, R.E. (Red.). $1990^{\circ}$. The Concise Oxford Dictionary of Current English. Oxford: Oxford University Press.

Cowie, A.P. (Red.). 19894. Oxford Advanced Learner's Dictionary. Oxford: Oxford University Press.

Grearson, Penny en Elaine Higgleton (Reds.). 1996. Chambers-Macmillan South African Student's Dictionary. Manzini: Macmillan Boleswa. 
Labuschagne, F.J. en L.C. Eksteen. 1993'. Verklarende Afrikaanse Woordeboek. Pretoria: J.L. van Schaik.

Mackensen, L. (Red.). 1977'. Deutsches Wörterbuch. München: Südwest Verlag.

Odendal, F.F., P.C. Schoonees, C.J. Swanepoel, S.J. du Toit en C.M. Booysen. 1994 ${ }^{3}$. Verklarende Handwoordeboek van die Afrikaanse Taal. Midrand: Perskor.

Schoonees, P.C. - D.J. van Schalkwyk. (Reds.) 1970-1996. Woordeboek van die Afrikaanse Taal. Pretoria: Die Staatsdrukker/Stellenbosch: Buro van die Woordeboek van die Afrikaanse Taal.

Sinclair, John (Red.). 1995. Collins Cobuild English Dictionary. Londen: HarperCollins.

Wahrig, Gerhard (Red.). 1987'. Deutsches Wörterbuch. München: Mosaik Verlag.

Woordeboek van die Afrikanse Taal. Kyk Schoonees - Van Schalkwyk (1970-1996).

\section{Ander bronne}

Beyer, Herman Louis. 1995. Die leksikografiese hantering van morfologies gemerkte geslagsopposisiepare in Afrikaanse woordeboeke, met spesifieke verwysing na die Verklarende Handwoordeboek van die Afrikaanse Taal. Ongepubliseerde M.A.-skripsie. Universiteit van Stellenbosch.

Beyer, Herman L. 1997. Aard en leksikografiese hantering van sogenaamde geslagtelik neutrale lede van Afrikaanse geslagsopposisiepare. Suid-Afrikaanse Tydskrif vir Taalkunde 15(4): 107. 115.

Beylefeld, Adri en Gert van Jaarsveld. 1994. Is die wêreld manlik, tensy anders vermeld? SuidAfrikaanse Tydskrif uir Taalkunde 12(2): 43-49.

Combrink, J.G.H. 1990. Afrikaanse morfologie. Capita exemplaria. Pretoria: Academica.

De Stadler, L.G. 1989. Afrikanse semantiek. Johannesburg: Southem.

Fouché, Michele. 1990. ' $n$ Evaluering van die semantiese inligting in die Verklarende Handwoordeboek van die Afrikaanse Taal. Ongepubliseerde M.A.-skripsie. Universiteit van Stellenbosch.

Gouws, R.H. 1989. Leksikografie. Pretoria/Kaapstad: Academica.

Ilson, Robert F. 1987. Towards a Taxonomy of Dictionary Definitions. Ilson, Robert (Red.) 1987. A Spectrum of Lexicography: 61-73. Amsterdam: John Benjamins.

Romaine, Suzanne. 1994. Language in Society. An Introduction to Sociolinguistics. New York: Oxford University Press.

Spender, Dale. 1980. Man Made Language. Londen: Routledge \& Kegan Paul.

Van der Merwe, Michele. 1994. 'n Evaluering van die Verklarende Handwoordeboek van die Afrikaanse Taal as standaard verklarende woordeboek. Tydskrif vir Geesteswetenskappe (36)4: 231236.

Zgusta, Ladislav. 1971. Manual of Lexicography. Praag: Academia/Den Haag: Mouton. 